\title{
ESSAY
}

\section{Government Lawyers' Ethics in a System of Checks and Balances}

\author{
Geoffrey P. Miller $\dagger$
}

The Secretary of Education decides to provide federal funds to parochial schools for the removal of hazardous asbestos insulation. The legal work incident to the program is assigned to Chris Langdell, a young lawyer in the Education Department honors program. Langdell discovers a recent 6-3 opinion of the Supreme Court striking down, on Establishment Clause grounds, a program of federal aid for new fire escapes in parochial schools. In addition, Langdell finds an Attorney General's opinion, issued during the prior administration, holding that an earlier asbestos removal proposal was both outside the Secretary's statutory powers and unconstitutional. Langdell knows that the Education Secretary's decision is based on a desire to garner political support from parents of parochial school children and on an ideological commitment to parochial schools. Would it be unethical for Langdell to work on the matter?

This hypothetical case presents an extreme example of the ethical conundrums that confront federal agency attorneys from time to time. I want to use the fact pattern to explore some intuitions about the ethical responsibilities of government lawyers. ${ }^{1}$ Many of these intuitions are premised on assumptions about the nature of the interest that the government attorney is charged with

† Professor of Law and Associate Dean, The University of Chicago. Attorney Advisor, Office of Legal Counsel, Department of Justice, 1981-1983.

1 Government lawyers are subject to the code of ethics of the state bar of which they are members, which in practice means some version of the American Bar Association's Model Code of Professional Responsibility or Model Rules of Professional Conduct. These ethics codes, however, do not provide clear answers to the problem posed in this essay because they were written with private, not government, attornies in mind. The analysis here depends on structural considerations of the agency lawyer's role in American government. 
serving. ${ }^{2}$ Once these assumptions are identified, it is possible to explore the rationale behind them. In my view, the proper identification of the interest served depends on an analysis of the role of the attorney within a framework of separation of powers and checks and balances. That analysis, in turn, demonstrates that an agency attorney acts unethically when she substitutes her individual moral judgment for that of a political process which is generally accepted as legitimate.

One common intuition is that the government attorney should do what she considers to be right under the circumstances, and that in appropriate cases doing what is right can and should trump the attorney's duties of loyalty to her agency, the President, or even the government as a whole. Assume, for example, that Langdell feels very strongly that the separation of church and state is crucial to the maintenance of American values and freedoms. In this circumstance he may have an easy out by requesting reassignment to something less problematic. Yet, Langdell may want to participate in order to prevent a result he perceives as dangerous and unjust. Would it be unethical for him to accept the assignment but leak the details to the press or the ACLU in hopes that the program will be politically stymied? What about working on the project but attempting to blunt its force with fine-print restrictions, thus knowingly frustrating the Secretary's policy objectives? Government attorneys have been known to engage in these tactics and more when they strongly opposed the policies of their superiors.

The intuition that might justify sabotage of this type is, I think, based on the premise that government attorneys owe special ethical duties not applicable to the ordinary lawyer. They represent the "public interest." The unique nature of that representation carries with it special responsibilities. Accordingly, they must be especially punctilious in exercising their authority consistently with overarching public needs.

Despite its surface plausibility, the notion that government attorneys represent some transcendental "public interest" is, I believe, incoherent. It is commonplace that there are as many ideas

2 This inquiry is often conceptualized as one of discovering who is the "client" of a government attorney. In the case of government attorneys, however, the notion of a "client" can be misleading because it evokes relationships between private lawyers and people who use their services that have little in common with the role of the government attorney. See Robert P. Lawry, Who is the Client of the Federal Government Lawyer? An Analysis of the Wrong Question, 37 Fed.Bar J. 61 (Fall 1978). 
of the "public interest" as there are people who think about the subject. Langdell may believe in the separation of church and state; his superior may believe that church-state separation is inconsistent with the nation's historical experience and present needs. If attorneys could freely sabotage the actions of their agencies out of a subjective sense of the public interest, the result would be a disorganized, inefficient bureaucracy, and a public distrustful of its own government. More fundamentally, the idea that government attorneys serve some higher purpose fails to place the attorney within a structure of democratic government. Although the public interest as a reified concept may not be ascertainable, the Constitution establishes procedures for approximating that ideal through election, appointment, confirmation, and legislation. Nothing systemic empowers government lawyers to substitute their individual conceptions of the good for the priorities and objectives established through these governmental processes. Accordingly, the initial intuition, which suggested that sabotage might be justified as a means of combatting a bad policy, seems seriously misguided.

Let us consider a second intuition about Langdell's situation. It might seem a matter of grave concern that his duties involve working towards a result that flies in the teeth of a recent, apparently authoritative Supreme Court ruling, or that the program in question may not be authorized by Congress. There is a strong surface plausibility to the argument that a government attorney may not ethically participate in the creation of a program that may be unconstitutional under Supreme Court precedent or unauthorized by statute.

The argument is, I think, based on a misplaced assumption about the nature of the interest properly served by agency attorneys. Here the idea is that an agency attorney works for the government as a whole. This notion is not subject to the objection that it depends on an unanchored concept of the public interest. In fact, it assumes that the public interest is determined through the constitutional processes of government.

The problematic nature of Langdell's assignment arises because he seems to be disserving at least two branches of the government, the judicial and the legislative. The Supreme Court, after all, is the highest federal court and is-or asserts that it is-the final arbiter of questions of constitutionality. The Court has already determined that a closely analogous, perhaps legally indistinguishable, executive action was unconstitutional. If one serves the government as a whole, it is reasonable that the final determination of issues of law should be made by the Court, and that one 
should prefer the Court's guidance on legal matters to determinations made by other branches. Similarly, if one serves the government as a whole, it is reasonable that one should act' according to one's best assessment of the laws that Congress has passed, since Congress is the branch principally charged with making policy. Thus, if it is more likely than not that the contemplated program is unauthorized by Congress or contrary to Supreme Court precedent, it would be unethical to take any part in it.

The notion, however, that an agency attorney serves the government as a whole is misplaced. It fails to situate the attorney within a system of separation of powers and checks and balances. The framers created three departments of government, according to Madison, in order to avoid the accumulation of all powers in the same hands, a condition that "may justly be pronounced the very definition of tyranny."3 Mere "parchment barriers"4 between the branches would not prevent tyranny, because power is of an "encroaching nature." To prevent the gradual concentration of powers in a single department, therefore, it was necessary to give to "those who administer each department the necessary constitutional means and personal motives to resist encroachments of the others." Ambition would counteract ambition, and the government would gain needed stability through a dynamic tension of opposing forces.

In a system of checks and balances it is not the responsibility of an agency attorney to represent the interests of Congress or the Court." Those departments have their own "constitutional means and personal motives" to protect their prerogatives. As a result, the constitutional system presumes-indeed, depends upon-the institutional loyalty of its lawyers. Congress has manifold opportunities-including powers of purse, oversight, investigation, and impeachment-to punish presidents or cabinet officers who do not administer the law to its liking. It does not need the allegiance of agency attorneys to fulfill its constitutional functions. The Court, for its part, has the power to issue judgments in controversies that come before it, and, in appropriate cases, to order the executive branch to take or refrain from taking specific actions. The Court's

${ }^{3}$ Federalist 47, in Clinton Rossiter, ed., The Federalist Papers 300, 301 (1961).

- Federalist 48,in The Federalist Papers 308.

B Id.

' Federalist 51, in The Federalist Papers 320, 321-22.

T The responsibility of an agency attorney is to represent the interests of the officer who has the legitimate power to decide upon the course of action, as I suggest in my discussion of the Attorney General's opinion, below. 
opinions are backed by substantial political capital and institutional prestige, such that the executive branch would inevitably suffer political costs-not to mention a loss of credibility in the Court itself-if it acted contrary to prior opinions.

All this suggests a line between actions taken by executive officials in the putative exercise of their constitutional authority, on the one hand, and actions not backed by a bona fide claim of authority, on the other. Where there is a bona fide claim of authority to act, the Madisonian understanding of separation of powers suggests that the action is likely to be a legitimate "constitutional means" by which the executive branch protects its interests vis-avis the other branches. Where, however, no bona fide claim of constitutional authority exists, the Madisonian understanding does not operate and the proposed actions would be inappropriate.

The solution to the ethical dilemmas faced by an attorney in Langdell's position thus turns upon the presence or absence of constitutional authority for the course of action he is asked to pursue. For example, it would no doubt be unethical for Langdell to work on the project in exchange for a bribe from an interested member of the public even if the matter were within his otherwise legitimate authority. Quite apart from its obvious personal immorality, bribery is independently illegal and Langdell can have no claim of constitutional authority for such behavior. It would also be unethical for Langdell to assist his superiors in disobeying a Supreme Court decision in a case to which they were a party, because actions in derogation of Supreme Court judgments cannot be said to be pursuant to a bona fide claim of constitutional authority. And it would be unethical for Langdell to assist his superiors in taking an action for which he believes his superiors have no claim of statutory authorization, since without statutory authority there is again no bona fide claim of constitutional power to act.

It would not, however, be unethical for Langdell to assist in a project that probably would be held unconstitutional under existing Supreme Court precedent so long as the project is not contrary to any binding judgment and the executive branch makes a bona fide claim that the Supreme Court's prior decision is incorrect. The executive branch certainly has constitutional authority to seek the overruling of prior court decisions. And it would not be unethical for Langdell to work on the project, even if it is arguably unauthorized by statute, so long as his superiors make a bona fide claim that the statute, properly construed, does authorize the project.

There is still, however, the problem of the prior Attorney Gen- 
eral's opinion. Quite apart from concerns about the public interest or the interest of the coordinate branches, there seems to be a strong intuition that at the very least it would be unethical for Langdell to ignore the opinion of the chief legal officer in the executive branch. This intuition seems premised on the view that the duties of an agency attorney run to the executive branch generally rather than to the agency only. I believe this view of the nature of the agency attorney's responsibility is essentially correct, although it needs to be explored carefully. An agency attorney operates within a constitutional structure in which the executive branch as a whole is treated as a single department. The unitary executive embodied in the Constitution is one in which officers and employees of executive departments report ultimately to the President. ${ }^{8}$ Accordingly, the attorney's obligation is most reasonably seen as running to the executive branch as a whole and to the President as its head.

But the conclusion, if it is accurate, that Langdell's duties run to the executive branch does not resolve the particular dilemma at hand. Would it be unethical to obey the instructions of his superior in the Department of Education when doing so runs counter to the opinion of the Attorney General? These questions of intrabranch conflicts can be subtle and complex, but in principle their answer is easy: the attorney's duties run to the officer who has the power of decision over the issue. In the vast majority of cases, that officer will be the head of the department in which the attorney works. A good rule of thumb is that while the attorney's ultimate duties run to the executive branch as a whole, the attorney reports only to the head of her department. There will be cases, however, where Congress or the President may designate some other officer as the decision maker. In such a case the decision of this other officer counts. If, for example, the President were to determine that certain agency regulations could not become effective until cleared by the Office of Management and Budget ("OMB"), ${ }^{8}$ then it would probably be unethical for an attorney to assist in the final promulgation of rules that had not received OMB clearance.

In the case of Attorney General opinions from previous administrations, the line is somewhat unclear. If the Attorney General

${ }^{8}$ This view of governmental structure is admittedly controversial. For justification, see Geoffrey P. Miller, Independent Agencies, 1986 Sup.Ct.Rev. 41.

- See generally Executive Order No. 12,498, 50 Fed.Reg. 1036 (1985) and Executive Order No. 12,291, 3 C.F.R. $\$ 127$ (1981) (OMB oversight of rulemaking by executive branch agencies). 
had issued regulations binding on the government as a whole pursuant to presidential or statutory authorization, the attorney's duty would be to comply with the regulation (subject, however, to the caveat that in cases of ambiguity the agency head's bona fide interpretation of the regulations would be controlling). But on the facts of the present hypothetical, the Attorney General's views were expressed in the form of a legal opinion. While the Attorney General is authorized to provide legal advice to the heads of departments, it is not entirely evident that the advice once given binds the recipient. Further, the advice in issue here was given in regard to a different, although substantially similar, program than the one presently under consideration. And it was given by an Attorney General who served in a previous administration that may have had very different policy judgments about the value of aid to parochial schools. In these circumstances, the agency attorney's duties to the executive branch might not encompass adherence to the views of a prior Attorney General. It would be a harder case, however, if the relevant opinion were by a current Attorney General who enjoyed the President's confidence and support.

All this suggests that it might not be unethical for Langdell to work on the program, despite its apparent inconsistency with views previously expressed by the Supreme Court, Congress, and the Attorney General. The general methodological point is that the scope of a government attorney's ethical responsibilities must be understood in the context of the attorney's role in a system of separation of powers. Once that role is held clearly in view, the answer to Langdell's ethical dilemma appears in a somewhat different light than initial intuitions might suggest. 